\title{
An Overview of Alternative Herbal Methods Applied in Cases of In Seasonal Common Cold Caused by Viruses
}

\author{
Esen Tasgin \\ Department of Nutrition and Dietetics, Faculty of Health Sciences, Ataturk University, Erzurum, Turkey
}

\begin{abstract}
The common cold caused by viruses is an infectious upper respiratory tract disease. A large number of viruses that cause the disease have been identified. Coronavirüs, parainfluenza respiratory synctial virus (RSV), influenza, rhinoviruses are mostly known as common cold-causing viruses. Often the common cold is self-limiting and shortterm disease. But, when it is evaluated in terms of quality of life and job losses, the magnitude of its effect is equivalent to chronic diseases. The lack of precise treatment and the desire to recover as soon as well has led to an increase in the orientation towards complementary alternative medicine practices besides drug treatments. One of the complementary alternative medicine practices is herbal treatment methods. In this study, herbal treatment methods used in the case of colds and their frequency of use were investigated. For this purpose, 298 students who were chosen randomly from the students studying in the Faculty of Health Sciences and who agreed to participate in the study were selected as the sample of the study. The reasons for using of the herbal products in colds by students and the levels of their use were tried to be determined.
\end{abstract}

Keywords: The common cold, Herbal treatment, Colds, Complementary alternative medicine

DOI: $10.7176 / \mathrm{JHMN} / 77-02$

Publication date:July $31^{\text {st }} 2020$

\section{Introduction}

The common cold is an upper respiratory disease caused by viruses in which the nasopharynx and paranasal sinuses are affected (Elaldi, 2005). It has been shown that more than 200 viruses can cause this disease, which has a wide range of effects in the world (Yahşi , 2017; Gökdemir and Ersu, 2010). The studies was shown that rinovirus which more than 100 subspecies is responsible for $50 \%$ of the common cold (Hendley, 2011; Boivin, 2002). The most effective viruses and their incidence are shown in Table 1 (Yalçın et al., 2007).

Table 1. Viruses and their incidence

Viruses

Frequency of Encounter

\begin{tabular}{lc}
\hline Rhinovirüs & $\% 50-80$ \\
\hline Coronavirüs & $\% 10$ \\
\hline Parainfluenza & $\% 7$ \\
\hline Respiratory synctial virüs (RSV) & $\% 10-15$ \\
\hline Other viruses (enterovirüs, rubeola, rubella, varicella) & $\% 5$ \\
\hline Undetectable viruses & $\% 20-30$
\end{tabular}

Immunity develops after disease caused by rhinovirus, adenovirus, coronaviruse and enterovirus species; however, due to the fact that it has more than one subspecies, it may be inadequate in recurrence of the disease. However, if the infection is the same factor when the infection is re-infected, the disease generally occurs milder and shorter time (Kirkpatrick 1997). Although the common cold is can be seen in all seasons of the year, expecially more common in autumn and winter. The common cold is more common in autumn and winter, but it can be also seen in all seasons of the year. It has been shown in studies that viruses that cause colds occur at different times of the year (Yahşi 2017; Monto 2002; Hendley 1998). The studies have been shown that people get being catch a colds 4 to 8 times in a year (Başal \& Günel 2014; Worrall 2007). Common cold symptoms may vary depending on age the patient's disease factor and age, and it generally can be seen runny nose, nasal congestion, sneezing, cough, burning sensation in the throat and rarely fever. The symptoms caused by the common cold last 1 to 2 weeks if no complications develop, and most patients feel better after the first week (Khamis et al., 2012). Cough; it occurs in two-thirds of the common cold and begins with nasal symptoms (Heikkinen \& Järvinen, 2003). Fever and constitutional symptoms are more common in influenza, human metapneumovirus, RSV, and cold in adenovirus compared to rhinovirus and coronavirus (Carlo 2011). However, in the recent days, it has been expressed that COVID-19 symptoms occured due to coronavirus are fever, cough, shortness of breath, body pain and weakness and even in advanced cases, pneumonia, respiratory failure might been also develop (Ikram \& Shahbaz,2020).

Because of the unconscious use of drugs among the public and the expectation of patients from the drug, some side effects, allergic reactions, food-drug interactions and toxic effects of these drugs are also increased (Aktay et al., 2003). So, it is important that medications were consumed at the specified time and at the recommended dose (WHO, 2002) with regard to rational drug use. Although the validity of modern medicine is 
effective today, serious side effects caused by drugs, drug - food and drug - drug interactions have led individuals to complementary medicine. Herbal therapy (phytotherapy), which forms part of Complementary and Alternative Medicine (CAM), is one of the alternative medicine methods used for centuries. These methods, which are used in the treatment of many diseases, are frequently used in case of cold (Diraçoğlu 2007). It is aimed reducting unnecessary drug using and in addition It is overcame these diseases with not-drug treatments.

The use of medicinal plants goes back thousands of years (Faydaoğlu \& Sürücüoğlu 2011) and a lot of society still use them regularly (Uzun et al. 2014; Aschwanden 2001). Plants contains phytochemicals that are known to be of great importance for human health (Top et al. 2019). Expecially, flavanoidler constitute the most important group of natural antioxidants in plants. They have many protective and therapeutic properties such as antibacterial, antifungal, anti-inflammatory, anti-allergic, neuroprotective, anti-aging, diuretic, anticinogenesis (Khamis et al., 2002; Pappas \& Hendley 2011). The studies indicate that various fruits and vegetables are effective on diseases such as cardiovascular diseases and cancer because of their antioxidant properties (Urhan et al. 2016). The use of plants in developed countries is based on scientific principles, standards are determined and recorded. The trend towards the use of medicinal plants, which have much less side effects than chemical drugs and whose treatment success has been proven, is increasingly in many countries (Özkan 2014). The most important problem in herbal treatment is the use of plants as if they were medicines. Because, when plants interact with drugs, among themselves and with nutrients, serious health problems can arise. The researches shown that in the metabolism of herbal product and drug interactions pharmacodynamic interactions appear to play a role (Merrily \& Kuhn, 2002; Dulger 2013). The previous research have been shown that contents of many medicinal plants that have biochemical importance can interact with drugs and cause many toxic problems (Kalkan 2017).

Many plants are used as supplements for the treatment of colds in the world. The most used of these are rosehip, flax seed, thyme, eucalyptus, turmeric echinacea, linden salvia, black pepper, fennel, st. john's wort, garlic, red gum tree. The usage areas of these plants and their biochemical significances are shown in Table 2.

Table 2. Herbal treatment supplements used in the common cold

\begin{tabular}{|c|c|c|c|c|}
\hline Plant & Contains & Biochemical effect & $\begin{array}{l}\text { Treatment } \\
\text { effect }\end{array}$ & References \\
\hline Rosehip & $\begin{array}{l}\text { Vitamin C } \\
\text { Phenolic Compounds } \\
\text { Carotenoids }\end{array}$ & $\begin{array}{l}\text { High antioxidant } \\
\text { activity }\end{array}$ & $\begin{array}{l}\text { strengthen the } \\
\text { immune system, } \\
\text { preventing colds and } \\
\text { flu-like infections }\end{array}$ & $\begin{array}{l}\text { Koca et al., 2008; } \\
\text { Koczka et al., } \\
2018\end{array}$ \\
\hline Flax Seed & $\begin{array}{l}\text { Hydroxybenzoic acid, } \\
\text { Vanillin, Coumaric acid } \\
\text { Ascorbic acid,Ferulic } \\
\text { acid } \\
\text { Ellagic acid }\end{array}$ & $\begin{array}{l}\text { High antioxidant } \\
\text { activity }\end{array}$ & $\begin{array}{l}\text { to reduce } \\
\text { inflammation, } \\
\text { to calm down, } \\
\text { to reduce colds, } \\
\text { coughs,fever }\end{array}$ & $\begin{array}{l}\text { Silva 2013; Han et } \\
\text { al. } 2018\end{array}$ \\
\hline Thyme & $\begin{array}{l}\text { Cinnamic Acid } \\
\text { Rosmarenic Acid } \\
\text { Methyl Rosmarenate } \\
\text { Apigenin, Nareingenin }\end{array}$ & $\begin{array}{l}\text { Antioxidant activity, } \\
\text { antimicrobial activity }\end{array}$ & $\begin{array}{l}\text { gastric-intestinal } \\
\text { complaints, } \\
\text { cough, bronchitis, } \\
\text { laryngitis, tonsillitis, } \\
\text { treatment of wounds }\end{array}$ & Roby et al. 2013 \\
\hline Eucalyptus & $\begin{array}{l}\text { mostly isorhamnetin and } \\
\text { quercetin, } \\
\text { phenolics }\end{array}$ & $\begin{array}{l}\text { Antibacterial, } \\
\text { antiviral, antifungal, } \\
\text { anti-inflammatory } \\
\text { antiseptic, } \\
\text { antioxidant, } \\
\text { anticancer, } \\
\text { antimicrobial } \\
\text { activities }\end{array}$ & $\begin{array}{l}\text { influenza, } \\
\text { pneumonia, } \\
\text { asthma and bronchitis } \\
\text { colds, cough, } \\
\text { laryngitis, sore throat } \\
\text { ect. }\end{array}$ & $\begin{array}{l}\text { Dağoğlu et al., } \\
\text { 2004; Brochot et } \\
\text { al.,2017; Grimm } \\
\text { \& Muller, } 1999\end{array}$ \\
\hline Echinacea & $\begin{array}{l}\text { polysaccharides, } \\
\text { essential oils, } \\
\text { mostly caffeic and ferulic } \\
\text { acid and other flavanoids }\end{array}$ & $\begin{array}{l}\text { Antiviral and anti- } \\
\text { inflammatory }\end{array}$ & $\begin{array}{l}\text { to increase the } \\
\text { immune system, in } \\
\text { the infectious diseases } \\
\text { in upper and lower } \\
\text { respiratory systems } \\
\text { toothache, bowel } \\
\text { pain, skin disorders, } \\
\text { cancer }\end{array}$ & $\begin{array}{l}\text { Grimm \& Muller, } \\
\text { 1999; Patel et al., } \\
\text { 2008; Mishima et } \\
\text { al., } 2004\end{array}$ \\
\hline
\end{tabular}




\begin{tabular}{|c|c|c|c|c|}
\hline Plant & Contains & Biochemical effect & $\begin{array}{l}\text { Treatment } \\
\text { effect }\end{array}$ & References \\
\hline Turmeric & curcumin & $\begin{array}{l}\text { Antioxidant, } \\
\text { anti-inflammatory, } \\
\text { antimutagenic, } \\
\text { antimicrobial, } \\
\text { anticancer }\end{array}$ & $\begin{array}{l}\text { espiratory system } \\
\text { diseases, } \\
\text { inflammatory } \\
\text { conditions, } \\
\text { loss of appetite, pain } \\
\text { joint diseases, cancer } \\
\text { kidney diseases }\end{array}$ & $\begin{array}{lr}\text { Karaman } & \text { and } \\
\text { Köseler, } & 2017 ; \\
\text { Hewlings } & \& \\
\text { Kalman } & 2017 ; \\
\text { Aggarwal } & \text { and } \\
\text { Harikumar } & 2009 ; \\
\text { Gupta et al. } 2013\end{array}$ \\
\hline Linden & $\begin{array}{l}\text { Flavonoids, essential oil } \\
\text { (1.8 cineol, camphor, } \\
\text { geranitol, thymol, } \\
\text { carvacrol, benzyl alcohol, } \\
\text { etc.), chlorogenic acid, } \\
\text { caffeic acid }\end{array}$ & $\begin{array}{l}\text { Diuretic, diaphoretic, } \\
\text { antipyretic, } \\
\text { anti-inflammatory, } \\
\text { antioxidant }\end{array}$ & $\begin{array}{l}\text { bronchitis, influenz } \\
\text { inflammation and } \\
\text { anxiety. }\end{array}$ & $\begin{array}{l}\text { Özok \& Çelik } \\
\text { 2019; Karakaya } \\
\text { \& El, } 2006\end{array}$ \\
\hline Salvia & $\begin{array}{l}\text { camphor, sabinol, } \\
\alpha \text {-thujone } \\
1,8 \text {-cineole }\end{array}$ & $\begin{array}{l}\text { Antioxidant } \\
\text { antimicrobial, } \\
\text { antibiotic, carnosol, } \\
\text { carnosoic acid, } \\
\text { rosmano }\end{array}$ & $\begin{array}{l}\text { colds, coughs, } \\
\text { nervous disorders, } \\
\text { intraoral } \\
\text { inflammation and } \\
\text { gingivitis }\end{array}$ & $\begin{array}{l}\text { Han et al. 2018; } \\
\text { Çoban \& Patır } \\
\text { 2010; } \\
\text { Grzegorczyk et } \\
\text { al., 2007. }\end{array}$ \\
\hline $\begin{array}{l}\text { Black } \\
\text { pepper }\end{array}$ & $\begin{array}{l}\text { essential oil for the aroma } \\
\text { the alkaloid compounds } \\
\text { for the pungency } \\
\text { piperine }\end{array}$ & $\begin{array}{l}\text { Antioxidant, } \\
\text { antimicrobial, } \\
\text { antipyretic }\end{array}$ & $\begin{array}{lr}\text { calming, } & \text { pain } \\
\text { relieving, } & \text { circulatory } \\
\text { and } & \text { digestive } \\
\text { regulating } & \end{array}$ & $\begin{array}{l}\text { Çoban \& Patır } \\
\text { 2010; Shlomo et } \\
\text { al, 2003; } \\
\begin{array}{l}\text { Mukhopadhyay } \\
2000\end{array}\end{array}$ \\
\hline Garlic & $\begin{array}{l}\text { allicin (allyl 2- } \\
\text { propenethiosulfinate or } \\
\text { diallyl thiosulfinate), } \\
\text { diallyl disulphide, S- } \\
\text { allylcysteine, and diallyl } \\
\text { trisulfide. }\end{array}$ & $\begin{array}{ll}\text { Anti-tumor, } & \text { anti- } \\
\text { microbial, } & \text { anti- } \\
\text { inflammation } & \end{array}$ & $\begin{array}{l}\text { cardiovascular } \\
\text { diseases, cancer, } \\
\text { blood pressure, } \\
\text { therosclerosis }\end{array}$ & $\begin{array}{l}\text { Rivlrn, 1998; } \\
\text { Bayan et al., } \\
\text { 2014; Fesseha \& } \\
\text { Goa 2019. }\end{array}$ \\
\hline Fennel & $\begin{array}{l}\text { fixed oil, essential oil, } \\
\text { protein, flavanoid, sterol, } \\
\text { sugar and apiol }\end{array}$ & Antioxidant & $\begin{array}{l}\text { dyspepsia, bloating, } \\
\text { gas and spasm in the } \\
\text { gastrointestinal tract, } \\
\text { to relieve nasal } \\
\text { discharge in upper } \\
\text { respiratory tract } \\
\text { infections (colds) }\end{array}$ & $\begin{array}{l}\text { Dă̆oğlu et al., } \\
2004\end{array}$ \\
\hline $\begin{array}{l}\text { St. John's } \\
\text { wort }\end{array}$ & $\begin{array}{l}\text { hypericin, hyperforin, } \\
\text { flavanoids, procyanidins, } \\
\text { vitamin C, carotene, } \\
\text { protein and essential oil }\end{array}$ & $\begin{array}{l}\text { Antioxidant, } \\
\text { antimicrobial }\end{array}$ & $\begin{array}{l}\text { wounds and burns } \\
\text { cancer, diabetes, } \\
\text { depression, chronic } \\
\text { rheumatism, } \\
\text { gastrointestinal } \\
\text { diseases, throat } \\
\text { infections, colds, } \\
\text { antiseptic }\end{array}$ & $\begin{array}{l}\text { Süntar et al., } \\
\text { 2010; Franchi et } \\
\text { al., 2011. }\end{array}$ \\
\hline
\end{tabular}

Apart from herbal supplements, the treatment supplements are such as vitamin $\mathrm{C}$, vitamin $\mathrm{D}$, and zinc are also frequently used. Researches have shown that vitamin $\mathrm{C}$ is effective in preventing infections and reducing the severity of cold symptoms, besides the its important role in connective tissue (Englard \& Seifter 1986; Hemila 2017). In addition, it is determined that vitamin $C$ is effective against pneumonia (Hemila \& Kaprio, 2008). It is known that the strong bone mineral structure needs vitamin D. Studies have identified a significant relationship between vitamin D and the immune system, and it has been shown that the risk and severity of infection is high in vitamin D deficiency (Laaksi et al., 2007; Quint et al. 2012; Cameron et al., 2013). Zinc, one of the basic elements for humans, takes part in many metabolic events in the body. Due to its effectiveness in the regulation of the immune system, a large number of diseases can occur in its deficiency (Haase \& Rink, 2014a; Gammoh \& Lothar, 2017). It has been shown in many studies that infectious diseases both such as tuberculosis, measles and pneumonia can lead. Similarly, it can be also caused to the emergence of many metabolic and chronic diseases such as diabetes and cancer (Gammoh \& Lothar 2017). It has been shown that zinc is effects the immune system and reducing 
antibody production (Haase \&Rink 2014b).

The purpose of this study; To examine the frequency of use of medicines and medicinal herbs and supplements used by Ataturk University Faculty of Health Sciences students in case of colds and to examine how this frequency changes according to sociodemographic data.

\section{Materyal and Methods}

2.1 Research Place, Time and Sample Selection

This study was planned as descriptive and was conducted to question the frequency of use of the medicines and complementary alternative herbal methods used by Erzurum Atatürk University Faculty of Health Sciences students in case of cold and to examine how this frequency varies according to sociodemographic data. The sample of the study consists of 298 adult individuals. Individuals over the age of 18 who are literate and accept to participate in the study voluntarily were included in the research. The faculty where the study was conducted was preferred because it provides health science education.

\subsection{Collection of Data}

The data of the study were collected by applying the questionnaire developed by the researcher via face to face interview technique. The questionnaire applied consists of 2 separate sections. In section 1, individuals' age, gender, educational status, etc. There are questions regarding sociodemographic features such as. Section 2 contains questions about their preferences about knowledge and attitudes about drug therapy and traditional therapy in general.

In obtaining research data, a questionnaire form prepared by support with the other studies and expert opinions was used. The questionnaire consists of 13 questions that determine demographic and individual information, and 13 questions that identify colds and attitudes towards the use of medicines and traditional herbal supplements consumed in this process. Students' attitudes towards drug use were measured by the answers given to likert-type expressions. In the questions, "Please mark the following medications according to your frequency of consumption", "Please mark according to your preference traditional methods of treatment of the common cold" and "What is the frequency of using the supplements you use in the treatment of the common cold?" The answers given to the questions were handled in 4 categories as "never", "rarely", "generally" and "often". In the evaluation of students' attitudes towards the use of medicines and traditional-complementary supplements, gender, age, living environment, chronic disease status were investigated with the $t$ test. In addition, the traditional-alternative supplements used in the case of colds and the frequency of their use, the reasons for individuals to turn towards traditional and complementary treatment, the way individuals provide their herbal products, the information sources used by individuals in traditional treatment methods have been determined as percentage values based on the number of participants.

\subsection{Statistical Evaluation of Data}

Study data were analyzed and evaluated using the SPSS 17.0 package program. Despite the qualitative (categorical) majority of the data collected as a result of the research, descriptive statistics were given first. Numbers and percentage tables were used in the evaluation of qualitative data. The results were evaluated at $95 \%$ confidence interval and significance level at $\mathrm{p}<0.05$.

\section{Results}

In this study was determined that 298 individuals included in the study were $89.6 \%$ female and $10.4 \%$ male. All of the participants are undergraduate students and $93.6 \%$ are between the ages of $18-24.35 .6 \%$ of the students stated that they lived with their families at home and $57.7 \%$ stated that they stayed in the dormitory. Demographic characteristics of the participants are shown in Table 3.

Table 3. Demographic characteristics of individuals

\begin{tabular}{lll}
\hline Age groups (year) & Number & $\%$ \\
\hline$\leq 18$ yaş altı & 15 & 5.1 \\
$18-24$ & 279 & 93.6 \\
$25 \leq$ & 4 & 1.3 \\
\hline Working status & Number & $\%$ \\
\hline Employees & 280 & 94 \\
Part-time employees & 10 & 3.3 \\
Employees when there is no school & 8 & 2.7 \\
\hline
\end{tabular}




\begin{tabular}{lll}
\hline Where lives & & \\
\hline Student residence & 172 & 57.7 \\
At home with friends & 18 & 6 \\
Family at home & 106 & 35.6 \\
Diğer & 2 & 0.7 \\
\hline Gender & & 89.6 \\
Famale & 267 & 10.4 \\
Male & 31 & \\
Total & 298 & \\
\hline
\end{tabular}

Although the proportion of individuals who said would expect the common cold to pass by itself was a little more, there were also participants who stated that they applied to drug in colds situation. In this group, they stated that they usually take colds medicines. The frequency of over-the-counter drug use for the treatment of colds was determined with the answer (\%) yes and (\%) no. Table 4 shows the frequency of over-the-counter medication for the treatment of colds, and Table 5 shows the frequency of over-the-counter medications and their use.

Table 4. Over-the-counter drug use in the treatment of colds

\begin{tabular}{lcc}
\hline Over-the-counter drug use & Frequency (number) & Frequency $(\%)$ \\
\hline Yes I'm using & 108 & 36,2 \\
No I do not use & 190 & 63,8 \\
\hline
\end{tabular}

Table 5. Over-the-counter drugs used to treat colds and their frequency of use

\begin{tabular}{|c|c|c|}
\hline Used drug & Frequency (number) & Frequency (\%) \\
\hline \multicolumn{3}{|l|}{ Painkiller } \\
\hline Never & 54 & 18,1 \\
\hline Rarely & 165 & 55,4 \\
\hline Usually & 61 & 20,5 \\
\hline Often & 18 & 6 \\
\hline \multicolumn{3}{|c|}{ Fever Reducer } \\
\hline Never & 123 & 41,3 \\
\hline Rarely & 135 & 43,3 \\
\hline Usually & 35 & 11,7 \\
\hline Often & 5 & 1,7 \\
\hline \multicolumn{3}{|l|}{ Nasal spray } \\
\hline Never & 135 & 45,3 \\
\hline Rarely & 102 & 34,2 \\
\hline Usually & 53 & 17,8 \\
\hline Often & 8 & 2,7 \\
\hline \multicolumn{3}{|c|}{ Phlegm Remover } \\
\hline Never & 184 & 61,7 \\
\hline Rarely & 79 & 26,5 \\
\hline Usually & 28 & 9,4 \\
\hline Often & 7 & 2,3 \\
\hline \multicolumn{3}{|c|}{ Cough mixture } \\
\hline Never & 156 & 52,3 \\
\hline Rarely & 113 & 37,9 \\
\hline Usually & 26 & 8,7 \\
\hline Often & 3 & 1,1 \\
\hline \multicolumn{3}{|l|}{ Aspirin } \\
\hline Never & 205 & 68,8 \\
\hline Rarely & 76 & 25,5 \\
\hline Usually & 16 & 5,4 \\
\hline Often & 1,0 & 0,3 \\
\hline \multicolumn{3}{|c|}{ Common Cold Pills } \\
\hline Never & 89 & 29,9 \\
\hline Rarely & 115 & 38,6 \\
\hline Usually & 73 & 24,5 \\
\hline Often & 21 & 7,0 \\
\hline
\end{tabular}

There was no statistically significant difference between the use of over-the-counter medication for the treatment of colds and gender, age group and educational status $(\mathrm{p}<0.05)$. It was interrogated quested frequency 
of drug, herbs and supplements used in the case of colds. The majority of the participants stated that they preferred to wait for the cold to pass instead of using medication. On the other hand, participants stated that they consume mixed herbal tea, green tea, roseship, cinnamon, mint-lemon, linden and vitamin $\mathrm{C}$ as supplements mostly in case of colds Table 6 .

Table 6. Frequency of herbs and Supplements Used in the Case of Colds

\begin{tabular}{|c|c|c|}
\hline Iron & $\mathrm{N}$ & $\%$ \\
\hline Never & 110 & 36.9 \\
\hline Rarely & 125 & 41.9 \\
\hline Usually & 40 & 13.4 \\
\hline Often & 22 & 7.4 \\
\hline Vitamin D & $\mathrm{N}$ & $\%$ \\
\hline Never & 102 & 34.2 \\
\hline Rarely & 112 & 37.6 \\
\hline Usually & 51 & 17.1 \\
\hline Often & 32 & 10.7 \\
\hline Vitamin C & $\mathrm{N}$ & $\%$ \\
\hline Never & 93 & 31.2 \\
\hline Rarely & 94 & 31.5 \\
\hline Usually & 61 & 20.5 \\
\hline Often & 49 & 16.4 \\
\hline Echinacea & $\mathrm{N}$ & $\%$ \\
\hline Never & 138 & 46.3 \\
\hline Rarely & 140 & 47.0 \\
\hline Usually & 13 & 4.4 \\
\hline Often & 6 & 2.0 \\
\hline Sage & $\mathrm{N}$ & $\%$ \\
\hline Never & 124 & 41.6 \\
\hline Rarely & 105 & 35.2 \\
\hline Usually & 50 & 16.8 \\
\hline Often & 18 & 6 \\
\hline S1k S1k & & \\
\hline Linden & $\mathrm{N}$ & $\%$ \\
\hline Never & 47 & 15.8 \\
\hline Rarely & 100 & 33.7 \\
\hline Usually & 102 & 34.2 \\
\hline Often & 48 & 16.2 \\
\hline Ginger & $\mathrm{N}$ & $\%$ \\
\hline Never & 113 & 37.9 \\
\hline Rarely & 74 & 24.8 \\
\hline Usually & 73 & 24.5 \\
\hline Often & 37 & 12.4 \\
\hline Mint and lemon & $\mathrm{N}$ & $\%$ \\
\hline Never & 34 & 11.4 \\
\hline Rarely & 57 & 19.1 \\
\hline Usually & 119 & 39.9 \\
\hline Often & 87 & 29.2 \\
\hline Cinnamon & $\mathrm{N}$ & $\%$ \\
\hline Never & 128 & 43.0 \\
\hline Rarely & 71 & 23.8 \\
\hline Usually & 59 & 19.8 \\
\hline Often & 36 & 12.1 \\
\hline Black Pepper & $\mathrm{N}$ & $\%$ \\
\hline Never & 188 & 63.1 \\
\hline Rarely & 61 & 20.5 \\
\hline Usually & 28 & 9.4 \\
\hline Often & 20 & 6.7 \\
\hline
\end{tabular}




\begin{tabular}{|c|c|c|}
\hline Eucalyptus & $\mathrm{N}$ & $\%$ \\
\hline Never & 271 & 90.9 \\
\hline Rarely & 16 & 5.4 \\
\hline Usually & 7 & 2.3 \\
\hline Often & 3 & 1.0 \\
\hline Rosehip & $\mathrm{N}$ & $\%$ \\
\hline Never & 106 & 35.6 \\
\hline Rarely & 87 & 29.2 \\
\hline Usually & 71 & 23.8 \\
\hline Often & 33 & 11.1 \\
\hline Fennel & $\mathrm{N}$ & $\%$ \\
\hline Never & 193 & 64.8 \\
\hline Rarely & 60 & 20.1 \\
\hline Usually & 33 & 11.1 \\
\hline Often & 11 & 3.7 \\
\hline Chamomile & $\mathrm{N}$ & $\%$ \\
\hline Never & 178 & 59.7 \\
\hline Rarely & 67 & 22.5 \\
\hline Usually & 38 & 12.8 \\
\hline Often & 14 & 4.7 \\
\hline Turmeric & $\mathrm{N}$ & $\%$ \\
\hline Never & 191 & 64.1 \\
\hline Rarely & 59 & 19.8 \\
\hline Usually & 34 & 11.4 \\
\hline Often & 12 & 4.0 \\
\hline Echinacea & $\mathrm{N}$ & $\%$ \\
\hline Never & 269 & 90.3 \\
\hline Rarely & 21 & 7.0 \\
\hline Usually & 6 & 2.0 \\
\hline Often & 1 & 3 \\
\hline St. John's Wort & $\mathrm{N}$ & $\%$ \\
\hline Never & 265 & 88.9 \\
\hline Rarely & 22 & 7.4 \\
\hline Usually & 8 & 2.7 \\
\hline Often & 2 & 7 \\
\hline Mixed herbal tea & $\mathrm{N}$ & $\%$ \\
\hline Never & 94 & 31.5 \\
\hline Rarely & 81 & 27.2 \\
\hline Usually & 83 & 27.9 \\
\hline Often & 39 & 13.1 \\
\hline Green tea & $\mathrm{N}$ & $\%$ \\
\hline Never & 78 & 26.2 \\
\hline Rarely & 98 & 32.9 \\
\hline Usually & 68 & 22.8 \\
\hline Often & 53 & 17.8 \\
\hline
\end{tabular}

Participants stated the sources of information they used in traditional treatment methods as family elders $(51.7 \%)$, media $(20.1 \%)$, doctors $(21.8 \%)$ and spice and herbal supplement vendor $(6.4 \%)$. In addition, the vast majority said that they obtained these products from spice and herbal supplement vendor (79.2\%), while others said they bought them from pharmacy and internet. The reasons of individuals towards traditional and complementary therapy are questioned and the results are shown in Table 7. 
Table 7. The reasons of individuals towards traditional and complementary therapy

\begin{tabular}{lll}
\hline & $\mathrm{S}$ & $\%$ \\
\hline The desire to get rid of the disease completely & 98 & 32.9 \\
Due to distrust / side effects on medicines & 82 & 27.5 \\
To support the treatment given by the physician & 72 & 24.2 \\
User experiences & 46 & 15.4 \\
\hline
\end{tabular}

When the relationship between the gender of individuals and supplements to the plant, vitamin C, vitamin D and iron intake was examined, no statistically significant relationship was found. The relationship between herbal supplements, vitamin $\mathrm{C}$, vitamin $\mathrm{D}$, iron intake and the gender of individuals with was investigated, and a statistically significant relationship was found only between gender and consumption of echinacea, St. John's wort and eucalyptus. It has been determined that women prefer these supplements more than men ( $\mathrm{T}$ test was applied, $\mathrm{p}>0.05)$. Considering the relationship between individuals' ages and herbal supplements and others only a statistically significant relationship was determined between the use of vitamin D and age of those aged 18 and under, while no relationship was found in others (Kruskal-Wallis test was applied, $\mathrm{p}>0.05$ ).

\section{Discussion}

Plants have been used in the treatment of many diseases for centuries. Therapeutic effects of plants are known and still used in many regions of the world. In addition, many related phytotherapy units are created in many countries. In recent years, interest in herbal supplements has increased even more in order to protect against the viral epidemics. Although middle and old age individuals have higher rates of use of such traditional supplements (Çetin 2007) the attitudes and usage rates of young groups for therapeutic properties of these plants are not known much. Numerous studies on complementary and alternative medicine have tried to measure the use of alternative medicine along with modern medicine and individuals' attitudes towards these treatments. Many problems encountered in modern medicine have been shown to lead individuals to the use of Complementary and Alternative Medicine (CAM) (Furhnam, 2007; Ameade et al., 2015). Usually, in the case of a cold, the majority expect the disease to go away on its own, rather than going to the doctor. There are also those who buy over-the-counter medicines from the pharmacy or apply herbal treatment to themselves (Demirci \& Şimşek, 2012). There are studies stating that students prefer to go to the doctor mostly in case of illness (Yilmaz et al., 2008). In another study, it was stated by students that herbal tea consumption is the most known method in alternative medicine applications Araz et al., 2012). Similar result has been determined Ameade et al. (2015) 's study with medical students (Ameade et al., 2015). Again, in a study on rational drug use with students, it was determined that the majority of students were against over-the-counter drug use (Demirci \& Şimşek, 2012).

According to the results of the study conducted to determine the attitudes of university students to use medicines, herbs and other supplements in the common cold, all students, mostly girls, are educated at the Faculty of Health Sciences. Although it was stated in the study that students preferred to go to the doctor in colds, most of them stated that they took herbal supplements during the treatment process. It is determined that those who apply herbal treatment mostly drink mixed herbal tea, mint- lemon, roseship, cinnamon, linden, green tea and vitamin C. They stated that students generally learned traditional medicinal plants usage information from the family. In drug treatment frequently; analgesics, nasal decongestants, cough syrups, expectorants and nasal sprays are used. In alternative treatment methods used, honey, garlic, fennel, eucalyptus, herbal teas, echinacea, vitamin $\mathrm{C}$, zinc are the most preferred ones. According to reports from the World Health Organization, the vast majority of people around the world use herbs and herbal supplements for therapeutic purposes, especially in colds diseases caused by viruses. The intake of herbal supplements is increasing, especially in common cold diseases caused by the viruses and without definitive treatment. In the other hand, the interaction of the plants used with other nutrients and drugs can cause many undesirable problems also. For this reason, it is extremely important to use the supplements under physician control and inform the patients and their relatives about this issue. It is especially important to determine the knowledge and attitudes of young people towards these treatment methods and to increase their knowledge sharing regarding the use of herbal supplements under Complementary and Alternative Medicine.

\section{Conclusions}

In drug treatment frequently; analgesics, nasal decongestants, cough syrups, expectorants and nasal sprays are used. In alternative treatment methods used, honey, garlic, fennel, eucalyptus, herbal teas, echinacea, vitamin $\mathrm{C}$, zinc are the most preferred ones. According to reports from the World Health Organization, the vast majority of people around the world use herbs and herbal supplements for therapeutic purposes, especially in colds diseases caused by viruses. The intake of herbal supplements is increasing, especially in common cold diseases caused by the viruses and without definitive treatment. In the other hand, the interaction of the plants used with other nutrients and drugs can cause many undesirable problems also. For this reason, it is extremely important to use the supplements under physician control and inform the patients and their relatives about this issue. It is especially 
important to determine the knowledge and attitudes of young people towards these treatment methods and to increase their knowledge sharing regarding the use of herbal supplements under Complementary and Alternative Medicine.

\section{References}

Aggarwal, B.B., Harikumar, K.B. (2009). Potential therapeutic effects of curcumin, the anti-inflammatory agent, against neurodegenerative, cardiovascular, pulmonary, metabolic, autoimmune and neoplastic diseases. Int. J. Biochem. Cell Biol. 41:40-59.

Aktay, G., Hancı, İ. and. Balseven, A. (2003). İlaç etkileşimleri ve hekim sorumluluğu. Sürekli tıp eğitimi dergisi.; 7:261-264

Ameade, EPK., Amalba, A., Gideon, KH., Muhammed, BS. (2015). Medical Students' Knowledge And Attitude Towards Complementary And Alternative Medicine- A Survey in Ghana. J Trad. Comp. Med., 1-7.

Aschwanden, C. (2001). Herbs for health, but how safe are they? Bulletin of the World Health Organization, 79: 691-692.

Araz, NC., Tastemir, HS., Kiliç, SP. (2012). Evaluation of the Views of the Faculty of Health Sciences Students on Non-Medical Alternative and Traditional Practices. Gümüşhane University Journal of Health Sciences, 1 (4), 239-251.

Başal, Y. \& Günel, C. (2015). Grip mi Nezle mi? Is It a Flu or Cold? Smyrna Tıp Dergisi. Sayı:55.

Bayan L. Koulivand PH and Ali Gorji A. (2014). Garlic: A review of potential therapeutic effects. Avicenna Journal of Phytomedical, 4(1): 1-14.

Boivin, G. (2002). Virological features and clinical manifestations associated with human metapneumovirus: a new paramyxovirus responsible for acute respiratory-tract infections in all age groups. The Journal of infectious diseases, 186(9), 1330-1334.

Brochot, A., Guilbot, A., Haddioui, A. and Roques, C. (2017). Antibacterial, antifungal, and antiviral effects of three essential oil blends, Microbiologyopen, 6(4): e00459.

Cameron, F. Gunville, CF., Mourani, PM. and Ginde, AA. (2013). The Role of Vitamin D in Prevention and Treatment of Infection, Inflamm Allergy Drug Targets, 11; 12(4): 239-245.

Carlo, W.N. (2011). Ambalavanan, and R. Kliegman, Nelson textbook of pediatrics. Respiratory Distress Syndrome. 581-590.

Çetin, OB. (2007). Eskişehir'de Tamamlayıcı ve Alternatif Tıp Kullanımı”. Sosyoekonomi, 2, 89-106.

Çoban, Ö.E. and Patır, B. (2010), Antioksidan etkili bazı bitki ve baharatların gıdalarda kullanımı. Gıda Teknolojileri Elektronik Dergisi, 5(2): 7-19.

Dağoğlu, G., Özbek H., Kati İ., Tekin M. (2004). Foeniculum vulgare (rezene) meyvesi eterik yağ ekstresinin analjezik etkisinin araştırılması. Yüzüncü Yıl Üniversitesi Veteriner Fakültesi Dergisi, 15(1): 23-26.

Demirci, A., Şimşek, I. (2012). Attitudes Of Using Medicine Of University Students, NWSA-Vocational Sciences, $7(4), 126-128$.

Dıraçoğlu, D. (2007). Romatoid artritte tamamlayıc1-alternatif tıpyöntemleri. Archives of Rheumatology, 22:2430.

Dulger, G. (2012). Herbal drugs and drug interactions. Marmara Pharmaceutical Journal. 16, 9-22.

Elaldi, N. (2005). Soğuk Algınlığı (Common Cold) ve İnfluenza. Turkiye Klinikleri Journal of Internal Medical Sciences, 1(28), 6-18.

Englard, S. (1986). Seifter, S. The biochemical functions of ascorbic acid. Annuals Rev. Nutrition, 6, 365-406.

Faydaoğlu, E. and Sürücüoğlu M.S. (2011). Geçmişten günümüze tıbbi ve aromatik bitkilerin kullanılması ve ekonomik önemi. Kastamonu Üniversitesi Orman Fakültesi Dergisi, 11(1), 52-67.

Fesseha, H. and Goa, E., (2019). Therapeutic Value of Garlic (Allium sativum): A Review, Advanced Food Technology Nutritional Science Open Journal, 5(3), 107-117. doi: 10.17140/AFTNSOJ-5-162.

Franchi, GG., Nencini, C, Collavoli, E \& Massarelli, P. (2011). Composition and antioxidant activity in vitro of different St. John's Wort (Hypericum perforatum L.) extracts. Journal of Medicinal Plants Research, 5 (17), 4349-4353.

Furhnam, A. (2007). A Modern Health Worries, Personality And Attitudes To Science Associated With The Use of Complementary And Alternative Medicine. British Journal of Health Psychology, 12 (2), 229-243.

Gökdemir, Y. \& R. Ersu, R. (2011). Soğuk Algınlığı. Turkiye Klinikleri Pediatric Sciences-Special Topics, 6(4): $39-45$.

Grzegorczyk, I., Matkowski, A. (2007). Wysokińska H, Antioxidant activity of extracts from in vitro cultures of Salvia officinalis L. Food Chemistry, 5,104, 36-541.

Grimm, W., Muller, HH. (1999). A randomized controlled trial of the effect of fluid extract of Echinacea purpurea on the incidence and severity of colds and respiratory infections. American Journal of Medical, 106,138-43.

Gammoh, NZ. \&Rink L (2017). Zinc in Infection and Inflammation. Nutrients, 2017 Jun; 9(6): 624.

Gupta, S.C., Patchva, S., Aggarwal, B.B. (2013). Therapeutic Roles of Curcumin: Lessons Learned from Clinical 
Trials. AAPS J. 15:195-218. doi: 10.1208/s12248-012-9432-8.

Haase, H., Rink, L. (2014a). Multiple impacts of zinc on immune function. Metallomics Integrated Bio-metal Science, 6,1175-1180.

Haase, H., Rink, L. (2014b) .Zinc signals and immune function. BioFactors, 40,27-40.

Han, H., Yılmaz H., Gülçin, İ., Antioxidant Activity of Flaxseed (Linum usitatissimum L.) shell and Analysis of Its Polyphenol Contents by LC-MS/MS, Rec. Nat. Prod. 12:4 (2018) 397-402.

Heikkinen, T. \& Järvinen, A. (2003). The common cold. The Lancet. 361(9351), 51-59.

Hemilä H. (2017). Vitamin C and Infections, Nutrients, 9,4.

Hemilä, H.; Kaprio, J. (2008). Vitamin E supplementation and pneumonia risk in males who initiated smoking at an early age: Effect modification by body weight and vitamin C. Nutritional Journal,. 7:33.

Hendley, J.O. (1998). Epidemiology, pathogenesis, and treatment of the common cold. Seminars in Pediatric Infectious Diseases. 9(1), 50-55

Hendley, J.O. (2011). The common cold and decongestant therapy. Pediatrics in review, 32(2), 47-55.

Hewlings SJ. And Kalman DS., (2017). Curcumin: A Review of Its' Effects on Human Health Foods. 6(10), 92.

Ikram, N. \& Shahbaz, H. (2020). Pandemic (COVID-19) Killing Thousands by the Hour-What the, Journal of Health, Medicine and Nursing, 73.

Kalkan, S. (2017). Bitkisel Ürünlerle Tedavilerde İlaç Etkileşmeleri Drug Interactions In The Treatment With Herbal Products DEÜ Tip Fakültesi Dergisi, 31,1, 49-58.

Karaman, B.E. \& Köseler E. (2017). Zerdeçalın Kronik Hastalıklarla İlişkisi. Başkent Üniversitesi Sağlık Bilimleri Fakültesi Dergisi-BÜSBID, 2(2).

Karakaya, S. \& El, SN. (2006). Total Phenols and Antioxidant Activities of Some Herbal Teas and In Bioavailability of Black Tea Polyphenols, GOÜ. Ziraat Fakültesi Dergisi, 23 (1), 1-8.

Khamis, F.A., Al-Kobaisi, M F, Al-Areimi, W S, Al-Kindi, H., Al-Zakwani, I. (2012). Epidemiology of respiratory virus infections among infants and young children admitted to hospital in Oman. Journal of Medical Virology, 84(8): 1323-9.

Kirkpatrick, G.L. (1996). The common cold. Primary Care: Clinics in Office Practice, 23(4), 657-675.

Karadağ, MG, Türközü, D, Kapucu, DT. Bitkiler ve ilaç etkileşimleri. Göztepe Tıp Dergisi. 2013;8:164-170.

Koca, I., Koc, A.F. \& Yolcu, H., Fonksiyonel gıda olarak kuşburnu. Türkiye, 2008; 10: 295-298.

Koczka, N., Stefanovits-Bányai, E. \& Ombódi, A. (2018). Total Polyphenol Content and Antioxidant Capacity of Rosehips of Some Rosa Species, Medicines, 5, 84.

Laaksi, I., Ruohola, JP., Tuohimaa, P., Auvinen, A., Haataja, R. (2007). Pihlajamaki H, Ylikomi T. An association of serum vitamin D concentrations $<40 \mathrm{nmol} / \mathrm{L}$ with acute respiratory tract infection in young Finnish men. Am J Clin Nutrition, 86(3):714-717.

Merrily, A. Kuhn, RN. (2002). Herbal Remedies: Drug-Herb Interactions. Critical Care Nurse. 22:22-35. 8.

Mishima, S., Saito, K. , Maruyama, H., Inoue M., Yamashita, T., Ishida, T., Gu Y. (2004). Antioxidant and Immuno-Enhancing Effects of Echinacea Purpurea, Biology and Pharmacology Bulletin, 27, 1004-9. doi: $10.1248 / \mathrm{bpb} .27 .1004$.

Monto, A.S. (2002). The seasonality of rhinovirus infections and its implications for clinical recognition. Clinical therapeutics, 24(12), 1987-1997.

Mukhopadhyay, M.. (2000). Natural Extracts Using Supercritical Carbon Dioxide: CRC Press (1st Ed.), Boca Raton.

Özkan, G. Phytotherapy, and Its Usage on Children, Turkiye Klinikleri J Fam Med-Special Topics, 5(4), 13-8.

Özok, N. \& Çelik, İ. (2014). Siçanlarda Ihlamur (Tilia platyphyllos Scop) İnfüzyonunun İmmün Sistem Üzerine Etkilerinin Araştırılması. Bitlis Eren Üniversitesi Fen Bilimleri Dergisi. 8(3), 852-858.

Pappas, DE., Hendley, J.O. (2011). The common cold and decongestant therapy. Pediatrics in review, 32(2): $47-$ 55.

Patel, T., Crouch A., Dowless, K., Freier, D. (2008). Acute effects of oral administration of a glycerol extract of Echinacea purpurea on peritoneal exudate cells in female swiss mice. Brain Behav Immunology, 22:39.

Rivlrn, RS. (1998). Patient with hyperlipidemia who received garlic supplements Lipid management. Report from the Lipid Education Council. 3:6-7.

Roby, MHH., Sarhan, MA, Abdel-Hamed, KH., Khalela, Kİ. (2013). Industrial Crops and Products Evaluation of antioxidant activity, total phenols and phenolic compounds in thyme (Thymus vulgaris L.), sage (Salvia officinalis L.), and marjoram (Origanum majorana L.) extracts, Industrial Crops and Product, 43, 827-831.

Shlomo, V., Adi R. \& Eliezer, K. (2003). The knowledge and expectations of parents about the role of antibiotic treatment in upper respiratory tract infection--a survey among parents attending the primary physician with their sick child. BMC Fam Practices, 4:20.

Silva, FGD. (2013). Antioxidant Capacity of Flaxseed Products: The Effect of in Vitro Digestion, Plant Foods Hum Nutrition, 68(1), 24-30.

Süntar, IP., Akkol, EK., Yılmazer, D., Baykal T. (2010). Kırmızıbekmez H, Alper M, Yeilada E. Investigation on 
the in vivo wound healing potential of Hypericum perforatum L.. Journal of Ethnopharmacol. 127: 468- 477.

Top, R., Erden Y., \& Tekin, S. (2019). Bazı önemli tıbbi bitkilerin antioksidan ve antikanser etkilerinin araştırılması. Bitlis Eren Üniversitesi Fen Bilimleri Dergisi, 8(2), 435-442.

Urhan, Y., Ege, MA., Öztürk, B., Elgin Cebe, G. (2016). Turkish food plants database. Ankara Üniversitesi Eczacılık Fakültesi Dergisi, 40(2), 43-57.

Uzun, M.B., Aykaç, G., and Özçelikay, G. (2014). Bitkisel Ürünlerin Yanliş Kullanimi ve Zararlari. Mersin Üniversitesi Tıp Fakültesi Lokman Hekim Tıp Tarihi Ve Folklorik Tıp Dergisi. 4(3), 1-5.

WHO, (2002). Promoting rational use of medicines: core components. Geneva: World Health Organization.

Worrall, G. (2007). Common cold, Canadian Family Physician, 53, 735-0736.

Quint, JK, Donaldson GC, Wassef N, Hurst JR, Thomas M, Wedzicha JA. (2012). 25-hydroxyvitamin D deficiency, exacerbation frequency and human rhinovirus exacerbations in chronic obstructive pulmonary disease. BMC Pulm Med. 12:28.

Yalçın, I., Salman, N., \& Somer, A. (2007). Çocuk Enfeksiyon Hastalıkları. Medya Tower Yayınları, Istanbul.

Yahşi, U.D.A. (2017). Soğuk Algınlığı. Klinik Tıp Pediatri Dergisi. 9(5), 16-20.

Yılmaz, E., Yılmaz, E., Karaca, F., Uçar, S. \& Yüce, T. (2008). Sağlık Yüksekokulu Öğrencilerinin İlaç Kullanma Durumlarının İncelenmesi. Firat Sağllk Hizmetleri Dergisi. 3(8), 69-82. 